\title{
The Identification of Facts and Legal Issues as First Steps Towards Fair Settlement of the Delimitation Dispute Over the Ambalat Block Between Indonesia and Malaysia
}

\section{Agustina Merdekawati}

International Law Department, Faculty of Law, Universitas Gadjah Mada. Jalan Socio Yusticia No. 1 Bulaksmur, D.I. Yogyakarta-Indonesia. 55281

\section{Abstract}

The purpose of this research is not to draw a conclusive limitation of the delimitation claims over Ambalat Block by both Indonesia and Malaysia. Rather this research shall act as a preliminary study to identify the issues and legal principles behind the dispute in order to reach an equitable sharing of resources. This research is a

Corresponding Author: Agustina Merdekawati agustina_merdekawati@ ugm.ac.id

Received: 2 April 2018

Accepted: 17 April 2018

Published: 23 May 2018

Publishing services provided by Knowledge

(c) Agustina Merdekawati. This article is distributed under the terms of the Creative Commons

Attribution License, which permits unrestricted use and redistribution provided that the original author and source are credited.

Selection and Peer-review under the responsibility of the 1St ICSEAS 2016 Conference Committee. legal research, thus the data collecting method emphasizes on literature research to obtain primary legal material, secondary legal material and non-legal materials, which afterwards analyzed qualitatively using statutory approach. The result of the research showed that: (i) According to the identified facts and law, both Indonesia and Malaysia possess potential to claim over the Ambalat Block which are affected by the judgment of International Court of Justice in 2002; (ii) The identified legal premise comprises of three legal problem that needs to be addressed in the negotiation which are (a) Whether Sipadan and Ligitan Island qualified to be identified as an island under article 121 of United Nations Convention of Law of the Sea 1982, (b) Is the principle of "effective control" applicable as the legal basis to claim over continental shelf and (c) is the principle of equitable solution detrimental to the determination of delimitation of continental shelf.

Keywords: Ambalat Block, continental shelf, dispute, Indonesia, Malaysia

\section{Introduction}

Noting the statement of Judge Shigeru Oda in the judgment of "The Sovereignty over Pulau Ligitan and Pulau Sipadon" between Indonesia and Malaysia in December 2002. Neither Indonesia or Malaysia was inherently interested to establish sovereignty over the islands, the underlying motivations of the disputing parties is actually to extend 
their claim over the continental shelf located in the Sulawesi Sea, which is now colloquially termed as the Ambalat Block, the dispute over this block remained unresolved to this day [1].

The dispute between Indonesia and Malaysia regarding the ownership of Ambalat Block are relatively old, the dispute firstly arises in 1969 when Indonesia and Malaysia started the negotiation to determine the delimitation of the continental shelf. Which throughout the course of negotiation included a survey conducted in 1974, it is within this survey that the Sipadan and Ligitan Island was uncovered in a terra nullius state. The dispute culminated in $21^{\text {st }}$ Dec 1979 when Malaysia extend the claim over the continental shelf unilaterally by including the Ambalat Block within the Malaysian Map, this action garnered substantial protest by Indonesia and other neighboring countries near the area [2]. Due to the foregoing protests, Malaysia was much more reserved in her claims and tend to engage in negotiation in resolving her maritime disputes. Even in light of the foregoing concession agreement concluded between Indonesia and multiple Multi-National Corporations near Malaysia's territories, Malaysia did not submitted protest nor was any action taken against Indonesia's expansion, thus indicating acquiescence.

However, this acquiescence was short-lived, following the judgment of "The Sovereignty over Pulau Ligitan and Pulau Sipadan" in International Court of Justice (IJC) in 2002, Malaysia became much bolder in enforcing her authority within and around her territories. Malaysia perceived the ICJ decision in 2002 granted her new foundations in claiming more territories. With the extended baselines drawn from the outermost islands which is Sipadan and Ligitan Island, Malaysia may now claim ownership over the Ambalat Block, however Indonesia contended that Malaysia have shown acquiescence and accepted Indonesia's authority over the block as she has never before rendered protest against Indonesia's management and exploitation of the block. This quandary calls for a fair and equitable settlement, considering that determination of these lines would rouse conflicts and collateral effects that may not be favorable for either parties.

Main problems identified in this study is what are the contended factual and legal issues relating to the Ambalat Block dispute that relevant in fair and equitable dispute settlement? This research is a normative legal research that identifies varying laws, regulations, state practices and principles under International Law, especially under Law of the Sea regime, either under International, Indonesian or Malaysian national law. This research emphasizes on library research to acquire secondary legal materials 
which later shall be used to process additional data acquired from interviews with relevant authorities.

\section{Identification of Facts Regarding the Dispute of Ambalat Block}

\subsection{Legal facts prior to Indonesia-Malaysian independence}

There two legal facts that are required to be noted prior to Indonesian and Malaysian independence (Indonesia at the time under Netherland control and Malaysia was under Great Britain control), that is: Firstly, Boundary Convention between Netherlands and Great Britain that are signed in London in $20^{\text {th }}$ June 1891 . Which in essence divided the territories of Dutch East Indies with the Kingdom of Britain. Secondly, the Territorial Zee en Maritieme Kringen Ordonnatie in 1939, that are stipulated in Staatsblad 1939 No. 442, this Ordonnantie stipulated that Indonesian territorial sea shall only extend to 3 nautical miles ( 1 mile $=1609344 \mathrm{~m}$ )

The relevant facts related to the present dispute are the fact that the 3 nautical-miles rules are only applicable in the Borneo Island, and that there are no established international rules regarding continental shelf and its delimitations. Furthermore, historically both states have no knowledge of the existence of the continental shelf [3]. Thus it is only unreasonable to assume that both of the states drawn the aforementioned agreement with due regard of the continental shelf in the Sulawesi Seas.

\subsection{Legal facts after Indonesia-Malaysian independence and prior to ICJ decision in 2002}

There are two prevailing perspective relating to the claims made over Ambalat Block, the following represents the legal facts in the perspective of Indonesia as disputing party:

- First point, Indonesia is entitled to declare its sovereignty over Ambalat Block as geographically speaking the block is located outside the territorial waters till maximum depth of between $1000 \mathrm{~km}$ to $2500 \mathrm{~km}$ with distance less than 200 miles. It's therefore fulfilled the qualifications as continental shelf according to Governmental Declaration on Indonesian Continental Base on 17 February 1969. In the $3^{\text {rd }}$ point of the declaration, the government announced that "in light of acceptance of the agreement on continental base boundaries with its neighbouring 
TABLE 1: Juridical facts relating to Ambalat Block from Indonesia law perspective.

\begin{tabular}{|c|c|}
\hline Time & Changes in Law \\
\hline $17^{\text {th }}$ Aug 1945 & $\begin{array}{l}\text { Indonesia proclaimed independence in 17th Aug } 1945 \text { and officially } \\
\text { considered as new state }\end{array}$ \\
\hline $\begin{array}{l}23^{r d} \text { Aug until } 2^{\text {nd }} \\
\text { Nov } 1949\end{array}$ & $\begin{array}{l}\text { Indonesia seceded all the Dutch East Indies territories under the principle of } \\
\text { uti possidetis }\end{array}$ \\
\hline $13^{\text {th }}$ Nov 1957 & $\begin{array}{l}\text { Indonesia proposed the concept of Archipelagic state which is further known } \\
\text { as the Djuanda Declaration of } 1957 f\end{array}$ \\
\hline $18^{\text {th }}$ Feb 1960 & Law number 4, 1960 regarding the Indonesian Waters \\
\hline $17^{\text {th }}$ Feb 1969 & Indonesian Government declaration of stance in relation to continental shelf \\
\hline $27^{\text {th }}$ Oct 1969 & $\begin{array}{l}\text { Indonesia started the negotiation process with Malaysia relating to the } \\
\text { continental shelf of Indonesia and Malaysia in Malaka Strait and South China } \\
\text { Sea }\end{array}$ \\
\hline $6^{\text {th }}$ Jan 1973 & Law number 1, 1973 regarding continental shelf in Indonesia \\
\hline $31^{s t}$ Dec 1983 & $\begin{array}{l}\text { Law number } 17,1985 \text { regarding the ratification of United Nations Convention } \\
\text { on the Law of The Seas }\end{array}$ \\
\hline $27^{\text {th }}$ July 1976 & $\begin{array}{l}\text { Law number } 1,1983 \text { regarding the ratification of the agreement between } \\
\text { Indonesia and Malaysia relating to the rights of Malaysia in Indonesian } \\
\text { territorial sea and airspace }\end{array}$ \\
\hline $8^{\text {th }}$ Aug 1996 & Law number 6,1996 on Indonesian Waters \\
\hline $29^{\text {th }}$ June 2002 & $\begin{array}{l}\text { Governmental regulation number 38, } 2002 \text { regarding the list of geographical } \\
\text { coordinates and coast baselines }\end{array}$ \\
\hline
\end{tabular}

countries, Indonesian government will issue licenses to conduct exploration and to extract oil and natural gas and to exploit minerals and other natural resources, only to territory on Indonesian side from a line that is drawn from the coast of Indonesia's outer islands". As a follow-up from the declaration, Indonesian have rendered concessions to several MNCs to conduct exploration and petroleum exploitation in the continental shelves around Sulawesi.

- Second point, In practice, the concessions made by Indonesia to several MNCs from 1966, have not been protested by any neighboring state, including Malaysia. Thus it could be concluded that despite Indonesia's unilateral claim on Ambalat there was an indirect acknowledgement from other countries, including Malaysia, that Indonesia held sovereign right over the territory, even more so with the fact that the MNCs came from different countries; These countries could be considered to have spawn acquiescence over Indonesia's sovereign right 
TABLE 2: Juridical facts relating to Ambalat Block from Malaysia law perspective.

\begin{tabular}{|c|c|}
\hline Time & Changes in Law \\
\hline $31^{\text {th }}$ August 1957 & Malaysia was given independence \\
\hline $21^{s t}$ July 1960 & $\begin{array}{l}\text { Malaysia ratified United Nation Convention on the Law of the Sea } \\
\text { (UNCLOS) I } 1958 \text { for convention on the high seas }\end{array}$ \\
\hline $21^{s t}$ July 1960 & $\begin{array}{l}\text { Malaysia ratified UNCLOS I } 1958 \text { for convention on fishing and } \\
\text { conservation of living resources in high seas }\end{array}$ \\
\hline $21^{s t}$ July 1960 & $\begin{array}{l}\text { Malaysia ratified UNCLOS I } 1958 \text { for convention on the continental } \\
\text { shelf }\end{array}$ \\
\hline $21^{\text {st }}$ July 1960 & $\begin{array}{l}\text { Malaysia ratified UNCLOS I } 1958 \text { for the optional protocol of } \\
\text { signature concerning compulsory settlement of disputes }\end{array}$ \\
\hline 21 & $\begin{array}{l}\text { Malaysia ratified UNCLOS I } 1958 \text { on the convention on the territorial } \\
\text { sea and the contiguous zones }\end{array}$ \\
\hline $2^{n d}$ August 1969 & $\begin{array}{l}\text { Malaysia extended her territorial sea to } 12 \text { nautical miles from } 3 \\
\text { nautical miles }\end{array}$ \\
\hline $27^{\text {th }}$ October 1969 & $\begin{array}{l}\text { Malaysia concluded the agreement with Indonesia regarding } \\
\text { continental shelf in Malaka Strait and South China Sea }\end{array}$ \\
\hline $21^{s t}$ December 1969 & $\begin{array}{l}\text { Malaysia published the new map showing the territorial limits and } \\
\text { continental shelf }\end{array}$ \\
\hline $27^{\text {th }}$ July 1976 & $\begin{array}{l}\text { Malaysia concluded an agreement with Indonesia relating to the } \\
\text { rights of Malaysia in Indonesian territorial sea and airspace process } \\
\text { with Malaysia relating to the continental shelf of Indonesia and } \\
\text { Malaysia in Malaka Strait and South China Sea }\end{array}$ \\
\hline $2^{\text {nd }}$ October 1996 & Malaysia ratified UNCLOS III 1982 \\
\hline
\end{tabular}

on the area. Additionally, Malaysia shown no active opposition and remained passive despite the declaration made over the continental shelf.

- Third point, Indonesia's ratification of 1982 UNCLOS strengthened the recognition over the continental shelf which was formerly regulated in law no 1 of 1973 , article 76 to 85 of UNCLOS allowed a more definite boundary to the definitions of continental shelf. In line with article 76 Indonesia may have a legitimate claim over the Ambalat Block due to its geographical position, and that Ambalat Block fulfilled the qualification laid down in article 76 of the 1982 UNCLOS.

- Fourth point, Based on an MoU between Republic of Indonesia and Malaysia dated in $27^{\text {th }}$ July 1976, Malaysia recognized the legal status of Indonesian archipelago, including recognition for Indonesia to draw archipelagic straight line in order to determine the outermost baseline. This includes the outermost points that is to the east of Northern Kalimantan, one of which is Karang Unarang. 
This recognition strengthened Indonesia's legal basis over its claim over the continental shelf in Sulawesi's Seas.

- Fifth point, Based on Governmental Regulation no 38 of 2002, Indonesia has a strong legal basis to assert claim over the Ambalat continental shelf with baselines on Sebatik Island-1, Sebatik Island-2, Karang Unarang, Karang Banda and Arang Cape (Bunyu Island). Taking into consideration article 121 (3), Karang Unarang are no longer considered as the baselines, but rather has to be pushed back 9.5 nautical miles to Sebatik Island. However this condition did not affect Indonesia's legal basis in the region considering the estimate of the area of the Ambalat block is merely 40 to 50 nautical miles from Sebatik Island (the distance allowed by continental shelf regime in UNCLOS III is 200 nautical miles).

On the other sides, there are other facts that may affect Malaysia to claim sovereignty over Ambalat Block, the aforementioned facts are:

- First Point, When Malaysia ratified UNCLOS 1958, facts have shown that Malaysia did not possess the technological capability to explore beyond $200 \mathrm{~m}$ including towards Ambalat Block (more than $1000 \mathrm{~m}$ ). This was evident from many treaties that Malaysia made at the time that only revolved around the continental shelf in Strait of Melacca and South China Sea. Therefore, Malaysia did not have strong legal basis to assert its title right over Ambalat Block.

- Second Point, Based on Emergency Essential Ordinance, No. 7/1969. Malaysia is not strong enough reason to assert its claim over Ambalat Block because that legal fact only changed the width of territorial sea and does not affect the width over the continental shelf, as both are based on the same baseline.

- Third Point, Based on Malaysia's 1969 map, Ambalat Block was included within the continental shelf of Malaysia, however in the context of international law, a unilateral drawn by the coastal state bear no particular legitimacy.

- Fourth Point, Based on Indonesia-Malaysia MoU of 1976, it can be concluded that this agreement does not affect Malaysia's position in the dispute, considering the MoU is merely act of recognition of Indonesia as an archipelagic state.

- Fifth Point, Based on UNCLOS III, Malaysia has the opportunity to draw a baseline from Mabul Island and Amil Island which means Malaysia has the opportunity to assert claim over the continental shelf. Thus even if Malaysia drawn the baseline from Mabul Island to Si Amil Island it would still be within less than 200 nautical miles radius, in accordance with article 76 of UNCLOS 1982. Additionally Malaysia 
did not respond in any way towards the concessions that Indonesian made since 1966.

\subsection{Legal facts after the ICJ decision $17^{\text {th }}$ December 2002}

IC) ruled that Malaysia had sovereignty over Sipadan island and Ligitan island, 16 judges voted in favour and one judge dissents. The decision was rendered in favour of Malaysia due to the application of principle of effective occupation. That under the consideration that during the British Government occupation, British had made several administrative actions over the disputed territories, including the issuance of law on conservation of species of birds, a tax levy against turtle egg collection since 1930 and the operation of certain lighthouse since the 1960's. ICJ verdict on the island of Sipadan and Ligitan have the potential to change the configuration baselines Indonesia and Malaysia around the Sulawesi Sea.

Malaysia put forward the argument that by obtaining the two islands as her new outermost point of Malaysian baselines it will also automatically change the configuration of the territorial sea. Following other zones such as the contiguous zone, Exclusive Economic Zone (EEZ) and continental shelf. With this argument, the Malaysia may have potential rights over Ambalat.

For Indonesia, the ICJ decision requires Indonesia to reconfigure her geographical coordinates of the outermost baselines, this in consequent cause a change of the territorial sea of Indonesia. The changes are then stipulated into the Indonesian Government Regulation No. 37 year 2008 on Amendment of Government Regulation No. 38 of 2002 on list geographical coordinates of baselines of Indonesia which effectively exclude Sipadan island and Ligitan island as a baseline. In accordance with article 16 of UNCLOS III, a list of the baselines coordinates must be posted to the UN Secretary General, of which was lodged in Mar 11, 2009.

The Judges of ICJ had predicted that the present judgment might affect not only the configurations of baselines of the territorial sea, but also affected future claims made on the Ambalat Block continental shelf. Thus under that reasoning, the judgment had warranted that the present judgment must not be construed as a conclusive decision for other cases of maritime delimitation cases, including other future continental shelf cases. Furthermore the judgment had included the recommendation for the disputing parties to ratify UNCLOS III, should consider their arrangements based on Article 83 of UNCLOS by applying the principle of "equitable solution". 


\section{Identification of Legal Issues that are Relevant to the Ambalat Block Dispute}

\subsection{Is Sipadan and Ligitan island qualified to be considered as island under article 121 of UNCLOS}

Article 121(2) and (3) of UNCLOS III stipulated that island that are considered to bear entitlements to claim Exclusive Economic Zones and continental shelf are islands that may support human habitation and capable to sustain economic life on its own. Rocks and islands that do not fulfill these criteria may not enjoy entitlements such as these, they may be qualified as baselines to extend territorial seas, but not for extending claims over the continental shelf [4]. Unfortunately, UNCLOS 1982 does not detailed the criteria of islands that fulfills the requirements of article 121(2) and (3).

In regard to the dispute on Ambalat Block, it is within Indonesia contention to see whether or not Sipadan Island and Ligitan Island fulfilled the criteria of island under article 121(2) and (3) to determine the claim over the continental shelf in Ambalat Block. Under article 121(2) and (3) the qualifications to be examined are: (a) Fulfilled the qualification as a land-that is a naturally formed "features" that are surrounded by water, and remain above the surface of water in high-tide condition; and (b) Fulfilled the qualification of island that supports human habitation and economic life on its own.

Considering that the article 121 of UNCLOS 1982 do not provide a clear and strict indication of the criterion. The writer referred to the interpretation of article 121 by the judges in PCA Judgement No. 2013-19 regarding the dispute of South China Sea between the Republic of Philippines and the People Republic of China of which ruled that:

i. Declared the Mischief Reef, Second Thomas Shoal, Subi Reef, Gaven Reef (South), Hughes Reef as low-tide elevations.

ii. Declared Scarborough Shoal, Gaven Reef (North), Mc Kennan Reef, Johnson Reef, Cuarteron Reef and Fiery Cross Reef as rock (high-tide features) that cannot sustain habitation or economic life of their own.

iii. Declared that none of the high-tide features in Spratly Island, in their natural condition, are capable of sustaining human habitation or economic life of their own.

Based on the decision, any islands/areas that do not qualify as island under article 121(2) and (3), qualified as rock/island that do not bear entitlements to claim over 
Exclusive Economic Zones (EEZ) nor continental shelf. The interpretation of article 121 UNCLOS 1982 is as follows:

\subsubsection{Interpretation of high tide elevation under article 121(1)}

Under article 121(1) it is clearly stipulated that an area could be identified as islands if such area remained to appear above the surface of the sea in high tide. The article do not stipulate a minimum size for a feature to be considered as rock or island, however the test rest on the fact whether a particular feature remained above surface on case of high tide elevation upon observation or surveys. In the case of South China Sea, the surveys are done by HMS Riflemen, HMS Hearld, Chinese Navy Headquarters, US Defense Mapping Agency Chart No. 93043 and US Sailings Directions. It could be concluded that there are no minimum of size of a feature, further quoting the decision of the ICJ in Territorial and Maritime Dispute (Nicaragua v. Colombia), it is stated that "international law does not prescribe any minimum size which a feature must possess in order to be considered an island" [5]. As a reference, the size and width of the features that was identified was: Cuarteron Reef $( \pm 5 \mathrm{~km})$, Gaven Reef $( \pm 23 \mathrm{~km})$, Johnson Reef $( \pm 54 \mathrm{~km})$, Hughes Reef $( \pm 29 \mathrm{~km})$, Mischief Reef $(20 \pm 27) \mathrm{km})$, Subi Reef $( \pm 5.75 \mathrm{~km})[6]$.

\subsubsection{Interpretation of article 121(3), "Rocks which cannot sustain human habitation or economic life of their own shall have no exclusive economic zone or continental shelf"}

\subsubsection{The existence of state practice}

There are three basic considerations and interpretations from PCA arbiters that was deployed to be tested on Sipadan and Ligitan. As the most important proving point, would be the geological technical aspects and the economy of the islands, and the results used to qualify if the islands could fulfil article 121 section (2) and (3) of UNCLOS 1982, these qualifications are:

i. The existence of military installation over the rock cannot be taken as a capability to "sustain human habitation or has an economic life as its own" by citing Vietnamese and Malaysian practice which deployed their troops on naval features with high tides element but do not claim entitlements 
TABLE 3: Interpretation of article 121(3) in PCA Judgement No. 2013-19 In Case Concerning South China Sea [5].

\begin{tabular}{|c|c|}
\hline Words in $121(3)$ & Interpretation \\
\hline Rocks & $\begin{array}{l}\text { The term rock in article } 12(3) \text { are not limited to geological features of a } \\
\text { certain rock, however it includes all features of minerals, either organic or an } \\
\text { organic that possess the solid consistency similar to those of rocks, or similar } \\
\text { to mud. Following the Precedence of IC) in Territorial and Maritime Dispute } \\
\text { (Nicaragua v. Colombia), whereas coral reefs Colombia Quitasueno are } \\
\text { identified as rocks. Thus the term rock are not limited to the meanings of } \\
\text { geo-morphological elements and features, but applied to all subcategories of } \\
\text { islands, or any naturally formed features. }\end{array}$ \\
\hline Cannot & $\begin{array}{l}\text { Cannot under article } 121(3) \text { refers to the question whether the sea feature in } \\
\text { question has the ability and potential to sustain human habitation or } \\
\text { economic life, it does not ask whether formerly in the past the features } \\
\text { possess that capability. This capability is determined whether presently it } \\
\text { may have the capability to sustain human habitation or economic life. }\end{array}$ \\
\hline Sustain & $\begin{array}{l}\text { "Sustain human habitation" at } 121(3) \text { referred to as the ability of a feature to } \\
\text { "support a stable group of human beings across significant numbers of } \\
\text { years" this include existence of clean water sources (fresh water), food } \\
\text { (food) and living space/material to create place of residence. All of this must } \\
\text { be naturally formed. There are three aspects of the word "Sustain": } 1 \text {. Ability } \\
\text { to provide } 2 \text {. Temporal qualification: The resources are not temporal and is } \\
\text { sufficient to provide for period of time (not one-off), and } 3 \text {. Qualitative } \\
\text { standard: The resources appear to meet the minimum standard of living. }\end{array}$ \\
\hline Human Habitation & $\begin{array}{l}\text { "Human Habitation" is interpreted as the ability for the human population to } \\
\text { occupy and live on the premises. With indicators that: } 1 \text {. The habitation of } \\
\text { this features is not temporary but permanent in nature. } 2 \text {. The population } \\
\text { here refers to a group of people, there is no minimum size in number. } 3 \text {. That } \\
\text { the area is qualitatively conducive and habitable, not merely to survive but to } \\
\text { have an appropriate living conditions. }\end{array}$ \\
\hline Or & $\begin{array}{l}\text { The term or are "the ability to sustain human habitation" or "Economic Life". } \\
\text { The criteria are not cumulative but alternative. So a feature that could } \\
\text { provide either one of the former requirement may acquire entitlement if he } \\
\text { either can sustain human habitation or economic life can sustain on its own. }\end{array}$ \\
\hline Economic Life & $\begin{array}{l}\text { Definition of "Economic Life" refers to the ability for the production, } \\
\text { distribution and transactions to support the local population there, it is not } \\
\text { just an indication of whether or not there exist certain resources in these } \\
\text { areas, but refers to the ability of a feature sea to provide materials and } \\
\text { resources for communities therein to transact and process goods and items } \\
\text { for sale. The word "life" emphasizes the existence of people who take } \\
\text { advantage of the economic potential there. The existence of these resources } \\
\text { is not a one-off or short lifed }\end{array}$ \\
\hline On their own & $\begin{array}{l}\text { The definition of "On their own" is defined as the ability to survive and thrive } \\
\text { without interference from outside, and are local in nature it does not rely on } \\
\text { imports, although this does not mean } 100 \% \text { independence or } \\
\text { Self-Sufficiency. The existence of these resources includes Territorial sea } \\
\text { around of the features sea it, and does not include economic activity in the } \\
\text { EEZ. It Allows presence of imports and external influence, however the } \\
\text { dependence on imported from outside should not be dominant, and should } \\
\text { be dominant from the island or the surrounding oceans. }\end{array}$ \\
\hline
\end{tabular}


ii. The non-existence of indigenous population showed that the location cannot sustain human habitation as there is no community that want to live there based on their own freewill

iii. The tendency of a small, uninhabited naval feature does not give entitlements. Example: UK which added its EEZ claim by extending it from Rockall and China in Oki-no-Tori-Shima, where Japan added its continental shelf by pointing out naval feature Oki no. 419.

To compare the aforementioned premises, with the conclusion drawn from ICJ decision on Sipadan and Ligitan which can be concluded that the islands disputes possess the following criterion:

i. Ligitan is a small island around 21 ha in area that is covered in rocks, weed and covered in trees known as bilang-bilang. Most of the islands are reef which are submerged and its highest points are between $0.3 \mathrm{~m}$ to $1.2 \mathrm{~m}$ above sea level. This island is uninhabited but huys could be found as a temporary shelter. This island is also often used to drying the fish by the fishermen.

ii. Sipadan is actually a peak of a oval-shaped seamount at $600 \mathrm{~m}$ under the sea. This island has a low profile which protrude for few metres above sea level. This 4 ha island is covered in tall trees in form of thick forests. There was no water on this island but few coconut trees and corn have been cultivated, there is also a well dug as a fresh water source and there was also a sea turtle reservation.

But these descriptions could not be used to test the qualifications of the island against article 121 of 1982 UNCLOS, and thus other methods must be adopted in order to allow better identifications of the status of an island.

\subsection{Whether principle of effective control could be used as a base for claim over continental shelf}

Based on identification of material facts above, be it in Indonesia and Malaysia, it can be concluded that in Ambalat Block there is an effective control by Indonesia which is recognized by Malaysia. This is indicated by the following:

First Point, Based on article 3 of Governmental Declaration on continental shelf, $17^{\text {th }}$ Feb 1969, Indonesia issued some concessions to several MNCs to explore and exploit the oil in continental shelf around Sulawesi. Those concessions were the following: 
i. Japex Block (Mahakam Block) in 1967, concession was given to Japan Petroleum Exploration Co., Ltd. (for 30 yr).

ii. North East Kalimantan Offshore Block in 1970, concession was given to Beyond Petroleum (BP)

iii. Bunyu Block in 1985, concession was given to Total Indonesie and continued by Hadson Bunyu BV.

iv. Bukat Block in 1988, concession was given to ENI Company from Italy.

v. East Ambalat Block, in 2004 the concession was given to Unocal Indonesia Ventures Ltd (Chevron)

vi. Ambalat Block, in 1999, concession was given to ENI from Italy.

Second Point, Based on the issuance of the various concessions in the area, Malaysia never raised any protests against Indonesia's action since 1966 [7-9].

Third Point, Having ratified UNCLOS III, Malaysia could have claimed the area of Ambalat Block but it never do so. However the question persist, does these evidences of effective control could amount to a strong legal reason to maintain Indonesian claim over the Ambalat block. The answer to this question can be found in UNCLOS III article 72 section (3) which stated that "The rights of the coastal state over the continental shelf do not depend on occupation, effective or national, or on any express proclamation". This means that various effective control acts that Indonesia has done could not be used as justification over Indonesia's sovereign right in Ambalat Block. Further consequences is that the existence for more room to redetermine the scope of sovereign right of respective countries in the area in accordance with article 83 of UNCLOS 1982 [10].

\subsection{What are the considerations in determining the equitable solution in determining the delimitation of the continental base}

In its decision on case regarding Sipadan-Ligitan, ICJ judges have recommended Indonesia and Malaysia to apply the principle of "equitable solution" in ending the dispute of continental shelves around Sulawesi which include the area of Ambalat block. The problem is that there is no operational definition in regards of the qualifications of the equitable solution. Article 38(1) UNCLOS 1982 only regulated that "The delimitation of the continental shelf between states with opposite or adjacent coasts 
shall be effected by agreement on the basis of international law, as referred to in article 83 of the Statute of the International Court of Justice, in order to achieve an equitable solution". Therefore, UNCLOS 1982 placed equitable solution as an end goal which the parties strived for while the mechanism to achieving that end is left to the parties in determining it.

This is different from the rules on delimitation for territorial sea which in article 15 of UNCLOS 1982 highlighted the primacy of the usage of the median line in determining the delimitation. Further in article 83 that only recommended the parties to negotiate, which if it failed, the dispute settlement is regulated in Chapter XV of UNCLOS 1982. As one of the refrences in understanding the principle of equitable solution, is the ICJ's decision in Case Concerning the continental shelf between Libyan Arab Republic and Malta, $3^{\text {rd }}$ of June 1985. In its decision, ICJ stated that: "the delimitation is to be effected in accordance with equitable principles and taking account of all relevant circumstances, so as to arrive at an equitable result." While several factors and circumstances that affect the determination of an equitable delimitation are the following:

i. The general configuration of the coasts of the parties, their oppositeness, and their relationship to each other within the general geographical context;

ii. The disparity in the lengths of the relevant coasts of the parties and the distance between them;

iii. The need to avoid in the delimitation any excessive disproportion between the extent of the continental shelf areas appertaining to the coastal State and the length of the relevant part of its coast, measured in the general direction of the coastlines.

Based on qualifications laid down above, Indonesia and Malaysia must explore the factors and special factors which are relevant and decisive in achieving equitable solution.

\section{Conclusions}

According to the research and analysis above, it can be well concluded that: First, Both Indonesia and Malaysia could extend her claim over the Ambalat Block, and thus potentially affecting the configuration of the ICJ decision in 2002. Second, That based on the foregoing discussion, it would be fruitful for both Indonesia and Malaysia to highlight the deliberation of law particularly in the discussion of: i) Whether Sipadan 
and Ligitan Island fulfilled the qualifications of island under 121 UNCLOS 1982; ii) Whether the principle of effective control could allow claims to be made on continental shelfs; iii) Whether equitable sharing principle applicable in determining delimitation of continental shelfs.

According to the conclusion above, the writer submits recommendations: First, That identification of law and facts are merely a part of the negotiation of the Ambalat Block, it requires further identification of geological and economical aspects and to identify political considerations. Second, Both of the negotiating state must emphasize and seek fair and equitable results, in accordance to the UN Charter and Part XV of UNCLOS. Third, Both of the negotiating states must approach the issue peacefully and refrain from resorting actions that may be provocative, as the particular subject are sensitive to the citizens of Indonesia and Malaysia.

\section{References}

[1] International Court of Justice. Declaration of Judge Oda. In: Case concerning sovereignty over Pulau Ligitan and Pulau Sipadan (Indonesia V. Malaysia) (Merits) Judgement of 17 December 2002, [online] from http://www.icj-cij.org/ docket/files/102/10570.pdf. (2002). [Accessed on 3 October 2016]. http: //www . icj-cij.org/files/case-related/102/10570.pdf

[2] Institute of Diplomacy and Foreign Relations (IDFR). 2009. Malaysia's Territorial Disputes-Two Cases at The ICJ. p. 115. Kuala Lumpur, Ministry of Foreign Affairs. https://www.idfr.gov.my/images/stories/publication/2009/inside_pbp.pdf

[3] Kusumaatmadja, Mochtar. Hukum laut Indonesia. p. 84. Binacipta, Bandung; 1986. p. 388.

[4] Ocean and Law of the Sea. Article 13 and 121 of UNCLOS 1982. In: United Nations Convention on the Law of the Sea. Geneva, United Nation; 2001. p. 202. http:// www.un.org/depts/los/convention_agreements/texts/unclos/unclos_e.pdf

[5] Permanent Court of Arbitration. The Tribunal's Consideration. In: PCA Case No. 2013-19 in the matter of the South China Sea Arbitration (The Republic of the Philippines v. The People's Republic of China) Award of 12 July 2016. p. 204. Hague, Permanent Court of Arbitration. p. 501. [online] from https://www.pcacases. com/web/sendAttach/2086. (2016). [Acessed on 4 October 2016] https://www . pcacases.com/web/sendAttach/2086

[6] Sebastian, CAF, Mumby P, Ward S. Assesment of the potensial environmental consequenses of construction activities on seven reefs in Spratly Island in South 
China Sea arbitration. [online] from https: //www. documentcloud.org/documents/ 2993893-Independent-Expert-Report-Coral-Reef-Environment.html (2016). [Accessed 10 October 2016]. https://www.documentcloud.org/documents/ 2993893-Independent-Expert-Report-Coral-Reef-Environment.html

[7] Druce, Stephen C, Baikoeni, Yoni E. Circumventing conflict: The Indonesia-Malaysia ambalat block dispute. In: Contemporary conflict in Southeast Asia: Towards a new ASEAN way of conflict management. Oishi M (Ed.). Springer, Singapore; 2016. p. 205. http://www . springer.com/gp/book/9789811000409

[8] Arsana IMA. Challenges and opportunities in the delimitation of Indonesia's maritime boundaries: A legal and technical approach. In: Univeristy of Wollongong Thesis Collections. p. 248-250. Wollongong, University of Wollongong Australia. p. 461 [online] from http://ro.uow.edu.au/cgi/viewcontent.cgi? article $=5047 \&$ context=theses (2014). [Accessed on 4 October 2016] http://ro. uow. edu. au/cgi/viewcontent. cgi?article=5047\&context=theses

[9] Forbes VL. 2014. Indonesia's Delimited Maritime Boundaries. Springer, Heidelberg; 2014. p. 266. http://www . springer. com/gp/book/9783642543944

[10] Schofield C, Arsana IMA. 2009. Beyond the Limits? Outer Continental Shelf Opportunities and Challenges in East and Southeast Asia. Contemporary Southeast Asia, 2009;31(1):28-63. http://www.jstor.org/stable/pdf/41288788.pdf? refreqid=search\%3Aab035238790752af17354802c47cc9dd 